\title{
Same-Sex Marriage in Ghana: Scripture, Health Law and Bioethics
}

\author{
John Kwaku Opoku ${ }^{1}$ Eric Manu ${ }^{1}$ Dorcas Mireku Appiah ${ }^{2}$ \\ 1.Department of Religious Studies, Kwame Nkrumah University of Science and Technology, Kumasi-Ghana \\ 2.Nkoranza Senior High Technical School, Bono-East, Ghana
}

\begin{abstract}
Same-sex relationship is not a recent phenomenon. In the Christian scripture (Leviticus 18:22 and 20:13) are traces of sexual prohibitions which have guided the morality of Christian marriage for years. Also, early colonial regulations in the Gold Coast (and perhaps other British colonies) contained strict prohibitions against homosexuality. In Ghana today, same-sex marriage is an illegal and ethical subject attracting diverse opinions. Whilst some Western countries recognize same-sex marriage and provide free movement as well as residency permits for same-sex couple, the marriage is repressed, criminalized and forbidden in most parts of Africa (if not entirely). The paper is to examine same-sex marriage and the extent to which scripture, health law and bioethics have shaped and informed attitudes toward homosexual activities in Ghana today. The paper examines Christian scriptural and bioethical responses which can serve as a means for co-existence.
\end{abstract}

Keywords: Same-sex marriage, Scripture, Health law, Bioethics, Co-existence

DOI: $10.7176 / \mathrm{DCS} / 11-4-04$

Publication date: April $30^{\text {th }} 2021$

\section{INTRODUCTION}

Same-sex relationship is not a recent phenomenon in Ghana. Before colonialism were traces of homosexual activities in the Gold Coast. Traditional homosexual relations had forced the British to enact laws to curb the activity in all her colonies including the Gold Coast. Early colonial regulations in the Gold Coast contained strict prohibitions against homosexuality. ${ }^{1}$ Among such regulations were the common law and criminal codes like the Indian Penal Code of 1860 and the Queensland Criminal Code of $1899 .{ }^{2}$ An examination of colonial regulations which were meant to prohibit same-sex relations evidently negates the idea that homosexual activities in Africa and perhaps Ghana was a colonial import. However, recent involvement in homosexuality is believed to have been boosted and sustained by modern globalisation.

Recent debates on same-sex marriage have focused on the rights, scriptural basis and social status which gays and lesbians possess. Presently, 28 jurisdictions worldwide have legalised same-sex marriage and for many others some level of civil partnership. In contrast, other jurisdictions refuse to recognise and even criminalise same-sex relationships. In the European Union (EU), member states are required by the Court of Justice to recognise same-sex marriages for the purpose of free movement and residency rights. ${ }^{3}$ The current trend is to see governments of developing and under-developed nations being persuaded or coerced to accept lesbians, gays, bisexuals and transgenders (LGBTs). This is to say that most decisions on same-sex marriage have come from the Western Liberal traditions.

In Ghana today, same-sex marriage remains illegal and homosexuals are heavily repressed and victimized. In the Criminal Code (Amendment) Act, 2003 (ACT 646), section 104 (1) (b), an unnatural carnal knowledge as perpetrated by Lesbians, Gays, Bisexuals and Transgender (LGBT) is criminalized and interpreted by the authorities as 'penile penetration of anything other than a vagina. ${ }^{4}$ What is generally expected of and by many Ghanaians is a union between people of the opposite sex (i.e. between a man and a woman); a form of marriage merely beyond the new bond between the couple but the entire extended families. This traditional understanding of marriage has ensured that gays and lesbians remained unaccepted, suppressed and abused. The question is that 'What is the contemporary understanding of marriage?', 'Has there been a change in the indigenous understanding of marriage?' and 'In what ways have scripture, law and bioethics influenced attitudes towards same-sex couple?' The paper as a result examines the concept of same-sex marriage and evaluates the extent to which religion, law and ethics have shaped Ghanaians' attitude towards gay and lesbian marriage today, while suggesting ways of co-existence.

\footnotetext{
${ }^{1}$ Rose Mary Amenga-Etego, "Marriage without Sex? Same-Sex Marriages and Female Identity among the Nakani of Northern Ghana," Ghana Bulletin of Theology 12 (2012): 24. Also see: Italo Signorini, "Nzema Kinship Terminology," Paideuma 24 (1978): 111.

${ }^{2}$ Enze Han and Joseph O'Mahoney, British Colonialism and the Criminalization of Homosexuality: Queens, Crime and Empire (London: Taylor \& Francis Limited, 2019); Stacey Hynd, "Criminal law." Privy Council Papers, accessed 23/04/2020, http://privycouncilpapers.exeter.ac.uk/contexts/law-and-the-british-empire/the-laws/criminal-law/.

${ }^{3}$ See Frances Hamilton and Guido Noto La Diega (eds), Same-Sex Relationships, Law and Social Change (Taylor \& Francis, 2020).

${ }^{4}$ Ghana's Criminal Law Statute is the Criminal Offence Act (1960) as amended Criminal Code (Amendment) Act, 2003 (ACT 646), accessed 23/04/2020, https:/www.ilo.org/dyn/natlex/docs/ELECTRONIC/88530/101 255/F575989920/GHA88530.pdf.
} 


\section{UNDERSTANDING SAME-SEX MARRIAGE}

The term marriage has several inferences. Some scholars explain it to mean the daily relationship experiences, ${ }^{1}$ while others think of it as the social institution of matrimony. ${ }^{2}$ Conventionally, marriage refers to a recognised institutionalised relationship backed by religio-cultural and civil laws. This understanding of marriage reiterates the views of Whitehead and Whitehead which state that marriage is a "social institution of matrimony which has legal definition and rights and duties that are regulated by the state and sanctioned in many religious traditions through special rights and ceremonies." Among some major religions, it is a natural and sacred institution, and

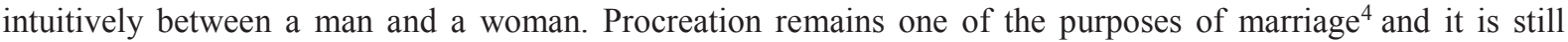
believed by many to be the most important functions of the union between a man and woman. The reason is that children are a sign of status, blessing and wealth. ${ }^{5}$

In contrast to the above understanding of marriage is the secularist view. This view has become a major tool of defence for the seemingly unconventional marriages today. Quoting Robert George's arguments, Holton explains the secular view of marriage as a legal agreement aimed at supporting a purely emotional union. ${ }^{6}$ Depending upon the subjective preferences of the partners, this union may or may not be marked by commitments of exclusivity and permanence, be open to children and in which sexual act of any kind mutually agreeable to the partners are perfectly acceptable. The argument is that whatever feels right or comes naturally to a person should determine the legitimacy and goodness of personal choices. ${ }^{7}$

In spite of the different meanings of marriage, three main types are accepted in Ghana: Ordinance, Customary and the Mohammedans Ordinance marriage (i.e.: Islamic marriage found mostly in Northern Ghana). ${ }^{8}$ Unlike elsewhere, especially Europe, marriage in Africa seems a requirement for both men and women in their 20s. In Ghana, it is a requisite stage, rather than an option. ${ }^{9}$ It is one of the most revered social institutions in both traditional and modern Ghanaian societies today.

Same-sex marriage, which is the central theme of this paper, is a topical and controversial issue in and outside Ghana's Christian community. It is a major issue among Muslims, Hindus, Jews and African Traditionalists. The phenomenon seems not to have lost its significance and controversy despite its antique origin. Often used interchangeably with the term homosexuality, same-sex relationship refers to the sensual, romantic and sexual attraction to a person of identical sex or gender. It as a predominant and persistent psychosexual attraction towards members of the same-sex. In this work, same-sex marriage implies the institutionalised recognised relationship involving either two males or two females.

At a time when America and Europe are allowing same-sex couple to marry and provide free movement as well as residency permits for same-sex couple, the marriage is repressed, criminalized and forbidden in Ghana and in most parts of Africa (if not entirely). Winter et al assert that same-sex marriage is backed by law in some countries including Canada, Belgium, Netherlands, South Africa, Spain, Sweden and Portugal, and under discussion in several more. ${ }^{10}$ Today, many nations condemn the practice and hold many negative views about same-sex marriage. In Ghana for instance, the concept of same-sex is unthinkable. It is even regarded as sinful and even punishable by death in some countries like Iran, Saudi Arabia, Sudan and Yemen.

The current trend in same-sex relationships appears not to be different from that of the previous years. For instance, over a decade ago, Samuel W. Kunhiyop reported of some trends like the demand for human rights and freedom of speech, erosion of traditional values, desire for morality to be based on empirical and scientific data and rejection of biblical revelation, ecclesiastical faith and practice. ${ }^{11}$ Today, lesbians and gays alongside bisexuals and transgenders continue to speak up similar agitations and seek legislation and even more advanced technologies to promote and protect their marriage and wellbeing. Meanwhile, the response of the Ghana government and religious and non-religious groups has always been one of dislike and anger. ${ }^{12}$

\footnotetext{
${ }^{1}$ John Corvino and Maggie Gallagher, Debating Same-Sex Marriage (New York: Oxford University Press, 2012), 184; Evelyn E. Whitehead and James D. Whitehead, "The Meaning of Marriage," in Contemplating Marriage: Reader, ed. Gloria Blanchfield Thomas (Wisconsin: Rowman \& Littlefield, 1995): 38.

${ }^{2}$ Murray Silberling, The Seven Year Contract: Fixing the Institution of Marriage (Booklocker.com Incorporated, 2013); B. S. Akande, Traditional Marriage Institution among Ogori/Magongo People of Kogi State (Lagos: Obaino Limited, 1997), 1-4.

${ }^{3}$ Whitehead and Whitehead, "The Meaning of Marriage," 38.

${ }^{4}$ Steven Schafer, Marriage, Sex and Procreation: Contemporary Revisions to Augustine's Theology of Marriage Vol. 240 (Wipf and Stock Publishers, 2019), 37.

${ }^{5}$ Steven J. Salm and Toyin Falola, Culture and Customs of Ghana (London: Greenwood Publishing Group, 2002 ), 130.

${ }^{6}$ Kevin T. Holton, The Abolition of Marriage: Freeing the Right to Be Religious and Leaving the left alone (London: Hamilton Books, 2020), 4-5.

${ }^{7}$ Holton, The Abolition of Marriage, 4.

${ }^{8}$ Salm and Falola, Culture and Customs of Ghana, 131

${ }^{9}$ Salm and Falola, Culture and Customs of Ghana, 130.

${ }^{10}$ Bronwyn Winter, Maxime Forest and Réjane Sénac, "Introduction," in Global Perspectives on Same-Sex Marriage: A Neo-Institutional Approach, eds. Bronwyn Winter, Maxime Forest and Réjane Sénac (London: Springer, 2017): 1.

${ }^{11}$ Samuel W. Kunhiyop, African Christian Ethics (Nairobi: Hippo Books, 2008), 305-306.

${ }^{12}$ Solace Brothers Foundation et al., Human Rights Violations against Lesbian, Gay, Bisexual and Transgender (LGBT) People in Ghana: A

Shadow Report (2016), 8, accessed 23/04/2020, https://tbinternet.ohchr.org/Treati es/CCPR/Shared\%20
} 


\section{SCRIPTURE, HOMOSEXUALITY AND SAME-SEX MARRIAGE}

When it comes to discussions on same-sex marriage, the Ghanaian Christian religious scene appears to be united with no sign of rethinking their stance. As the issue of homosexuality and same-sex marriage is dividing mainstream Protestants across the globe, all Christian denominations in Ghana unanimously hold antihomosexuality sentiments. The belief is that this position has been sustained due to the normative function of the Christian scripture ${ }^{1}$ as well as the understanding of the different roles of men and women contained in it. ${ }^{2}$ For Christians of today, like their predecessors, the assertion is that 'scritpura sacra locuta, res decisa est', meaning 'the scripture has spoken, the matter is decided'.

However, the somewhat general assertion is that "there is nothing positive within scripture about same-sex sexual relationship and a number of clearly negative text". ${ }^{3}$ Clearly, the scripture condemns all unnatural sexual intercourse or canal knowledge. In the book of Leviticus (18:22 and 20:13) are section of the holiness code and list of sexual prohibitions.

You shall not lie with a male as with a woman; it is an abomination. ${ }^{4}$

If a man lies with a male as with a woman, both of them have committed an abomination; they shall surely be put to death; their blood is upon them. ${ }^{5}$

An examination of the verses above is a clear prohibition of same-sex relationship if not to include LGBTs. More recent interpretations of the two texts emphasise its context of holiness (a code of purity) meant to differentiate the behaviour of God's people (Israelites) from non-Israelites (the polytheistic Canaanites). For instance, Janet Edmonds explains that the texts (which are part of The Clobber Verses") emphasise on "ritual purity for the Israelites, and setting guidelines for the Israelites to distinguish themselves from their pagan neighbours, the Egyptians and Canaanites, who lived in the lands before they were settled by the Jews."7 In her view, this ritual purity is seen in three specific scripture passages (i.e.: Leviticus 18:2-3, 18:24 and 20:23) cautioning the Israelites never to emulate what the Canaanites and Egyptians did.

On the contrary, some recent Bible scholars believe that the biblical purity ritual was a later introduction. For instance, Idan Dershowitz in one of his work "Revealing Nakedness and Concealing Homosexual Intercourse: Legal and Lexical Evolution in Leviticus 18" published in 2017 concludes that "there is good evidence that an earlier version of the laws in Leviticus 18 permitted sex between men." ${ }^{8}$ He believes the scripture passages condemning same-sex relationship was rewritten after studying the original version of the Old Testament (OT). His finding was that the original book of Leviticus permitted gay marriage. However, its later editor inserted the holiness code as an attempt to obscure any deleterious implication that same-sex marriage has had in early biblical communities. ${ }^{9}$

Until recent years, the verdict of the Christian scripture on same-sex marriage never appeared to be definite and clear among theologians and Christians. ${ }^{10}$ With reference to Genesis 19:1-11, homosexuality and same-sex marriage are considered as a gravely sinful act. ${ }^{11}$ The destruction of Sodom and Gomorrah reported in Genesis 19 has always been the basis for many of the condemnations that gays and lesbians face. Karl H. Peschke observes that a closer look at the above chapter reveals violations of the hospitality laws and sexual rape but not same-sex intercourse. However, the suggestion in Genesis 19 is that the men of Sodom who wanted to 'rape' Lot's visitors were homosexuals. Similarly, in the book of Judges Chapter 19 is the narration about a Levite who encountered homosexuals at Gibeah. The Levite was asked to be brought out of the house in which he lodged to be sodomised by the men of the town. The Old Testament does not present homosexuality whether as a medical, social or psychological situation; neither does it present gayism nor lesbianism as an innate quality.

Documents/GHA/INT_CCPR_CSS_GHA_24149_E.pdf.

${ }^{1}$ See the work of Wilfred Cantwell Smith, What is Scripture? A Comparative Approach (Minneapolis: Fortress Press, 1994).

2 Andrew Goddard, "Theology and Practice in Evangelical Churches," in The Oxford Handbook of Theology, Sexuality, and Gender, ed. Adrian Thatcher (Oxford: University Press, 2015), 390.

${ }^{3}$ Goddard, "Theology and Practice in Evangelical Churches," 390.

${ }^{4}$ Leviticus 18:22.

${ }^{5}$ Leviticus 20:13.

${ }^{6}$ The Clobber Verses refer to the seven verses about same-sex relationship (homosexuality): Genesis 19:1-14 and 24-26, Judges 19:1-30, Leviticus 18:22; 20:13, Romans 1:18-27 18, I Corinthians 6:9-10, I Timothy 1:8-11.

${ }^{7}$ Janet Edmonds, "An Analysis of the Seven Scriptures Often Referred to as 'The Clobber Verses"' (2017), accessed 17"th February, 2021, https://serendipitydodah.wordpress.com/2017/02/27/the-clobber-verses/.

${ }^{8}$ Idan Dershowitz, "Revealing Nakedness and Concealing Homosexual Intercourse: Legal and Lexical Evolution in Leviticus 18," Journal Hebrew Bible and Ancient Israel 6, no.4 (2017): 517. Also see "The Secret History of Leviticus" (July 21, 2018), accessed 3/09/2020, https://www.nytimes.com/2018/07/21/opinion/ Sunday/bible-prohibit-gay-sex.html.

${ }^{9}$ Like many ancient texts, Leviticus was created gradually over a long period and includes the words of more than one writer. Many scholars believe that the section in which Leviticus 18 appears was added by a comparatively late editor, perhaps one who worked more than a century after the oldest material in the book was composed. An earlier edition of Leviticus, then, may have been silent on the matter of sex between men.

${ }^{10}$ Karl H. Peschke, Christian Ethics: Moral Theology in the Light of Vatican II (Bangalore: Theological Publications, 2010), 283.

${ }^{11}$ In Catholic theology, this sin is also known as 'mortal sin'. Though of high gravity and can lead to damnation, repentance before death is an ultimate means of forgiveness of a gravely sinful act like homosexuality. 
One could object that the codes of conduct or rules of the Old Testament are not automatically valid for the New Testament, since the Old Testament has been replaced and surpassed by the New Testament (NT). However, in Romans (1:26-27), 1 Corinthians (6:9-11) and 1 Timothy (1:9-10), the Apostle Paul appears to reject same-sex intercourse and excludes homosexual from God's kingdom. The Apostle groups them in the same category as murderers, adulterers and idolaters.

Furthermore, the genetic make-up of males and females is a divine provision. In the creation narratives especially in Yahwist account (Genesis 2:1ff), both sexes were created to complement each other. It is through this complimentary nature that marital bonds, communion and stability is displayed. Therefore, sexual acts between the directly identical sexes cannot be term as an expression of love. Peschke's assertion is that "the readiness of a man and a woman to unite in the sexual act is therefore the sign of a high mutual esteem, at least if the union is accepted in its integral significance". ${ }^{1}$ Clearly, the position of scripture is a reflection of the outright rejection of the homosexual act in Christendom, and that "any attempt to justify homosexuality... is foreign to the scripture". 2

It must be stated that of significance to the Holy Scripture and theologians is the fundamentally positive attitude to marriages and family. For instance, in the books of Genesis (1 and 2), Matthew (19:1ff) and Ephesians (5:21-23) are positive expressions and evaluation of heterosexual, conjugal and procreation-oriented relationship. The result is that, in the general Christian and human sexuality understanding of conjugal union is an intrinsic relation to procreation, which make homosexual acts not to be in harmony with the meaning of sexuality deduced in the bible.

\section{HEALTH LAW AND SAME-SEX MARRIAGE}

There are findings from substantial body of researches that indicate significant barriers to healthcare for the LGBT communities. Especially, in countries where homosexuality has been legalised. However, there has not been specific legislation (health law) with regards to the health needs of homosexuals. What most governments are doing is to redraw regulations that discriminates or prohibits homosexuals from accessing quality healthcare provisions.

Scholars like Frances Hamilton and Guido Noto La Diega have underscored the importance of medical laws to same-sex couples. ${ }^{3}$ Like some health expert, Rachael Rettner in 2015, also writes with the conviction that the Supreme Court's verdict that same-sex couples in the United States have the right to marry will go a long way to improve their health. ${ }^{4} \mathrm{He}$ supports his belief with a body of evidence to show that couples who are heterosexuals have better holistic health than individuals who are not married. It is indeed true that not many studies have been done among same-sex couples in this respect, however, the few done seems to suggest that a legitimate and recognised union provide the same benefits for same sex couples.

\section{BIOETHICS AND SAME-SEX MARRIAGE}

Bioethics is an interdisciplinary branch of ethics in which doctors, theologians, lawyers and philosophers work together to resolve complex ethical and moral questions and dilemmas raised in the framework of modern healthcare. ${ }^{5}$ This branch of ethics has become relevant in this paper due to the timeless nature of the topical debates/dilemmas it attempts to resolve. On an issue like same-sex marriage, modern medicine and general secularization of society make bioethics one basic strategic area for thoughtful Christian involvement. Same sex marriage has also been one of the issues bringing a lot of complexities in the discipline with lots of ethical arguments being raised about this union, especially, in the areas of procreation (the use of Assisted Reproduction Techniques $)^{6}$ and healthcare provision.

As mentioned earlier, procreation remains one of the purposes for marriage ${ }^{7}$ and same-sex couples in marriage at a point in time desire to experience parenthood. Conception for same sex couples however, requires Assisted Reproductive Techniques (ARTs) such as In Vitro Fertilization, Surrogacy and Artificial Insemination. In countries such as United States where same-sex marriage has been legalized in some states, there has been an increasing demand from same-sex couples seeking parenthood. Greenfeld and Seli ${ }^{8}$ records that about 6 to 14 million children in the United States have been birthed by gay parent through ART. These ARTs on the other hand have been subjected to diverse debate as to whether their usage is ethically good or not.

\footnotetext{
${ }^{1}$ Peschke, Christian Ethics, 485.

${ }^{2}$ Kunhiyop, African Christian Ethics, 308.

${ }^{3}$ Hamilton and Diega, Same-Sex Relationships (2020).

4 Rachael Rettner, "How Same-Sex Marriage Ruling Could Improve Health," (2015), accessed 21 ${ }^{\text {st }}$ November, 2020, https://www.livescience.com/51368-same-sex-marriage-health.html.

${ }^{5}$ Walter A. Elwell, Evangelical Dictionary of Theology (Michigan: Baker Academic, 2001), 116.

${ }^{6}$ Dorothy A. Greenfeld and Emre Seli, “Assisted Reproduction in Same Sex Couples," in Bioethics: An Anthology $3{ }^{\text {rd }}$ Edition, eds. Helga

Kuhse, Udo Schuklenk and Peter Singer (West Sussex: Willey Blackwell Publisher, 2016): 80.

${ }^{7}$ Schafer, Marriage, Sex and Procreation, 37.

${ }^{8}$ Greenfeld and Seli, "Assisted Reproduction in Same Sex Couples," 74.
} 
It is widely known that ARTs are not acceptable by some Christian denominations such as the Catholic Church with arguments that ARTs involve disregard for human life (procedures involved) and separates human procreation from sexual intercourse ${ }^{1}$. Other arguments against the use of ART for same sex couples include a waste of medical resources and protection of the welfare of children, i.e., preventing children from being subjected to stigmatization (birthed by homosexuals). ${ }^{2}$ Thus, they hold the claim that there is the need to promote responsible procreation. Greenfeld and Seli in opposition to this view advocate that there is no pervasive evidence to suggest that children raised by same sex couples are harmed or disadvantaged. ${ }^{3}$ Therefore, same sex couples must be must be allowed to employ the available assisted reproductive techniques for their good.

Ronald Munson ${ }^{4}$ also employs the principles of autonomy and beneficence in medical ethics to support same-sex couples using ARTs for procreative purposes. With the prima facie duty of beneficence, individuals especially in the health care centers are obliged to assist others in making their lives better. This implies that same-sex couples using ARTs for procreative purpose is justified as means to the well-being of others. The principle of autonomy in this stead also entitles same sex couple to have the right to decide which technique they want for procreative purposes. So, if same-sex couple desires to have a child but unable to conceive one, then either in vitro fertilization procedures or artificial insemination and surrogacy might be employed to help them satisfy their shared desire.

Another area of concern in bioethics for same-sex marriage is the area of health. It can be asserted that people in same-sex unions are faced with challenges in health care (physical and mental) due to the judgmental attitudes from societies towards them. Their inability to disclose their sexual orientation to colleagues, health professionals and care givers increases their risk of psychological harm. ${ }^{5}$ Studies by Haber ${ }^{6}$ and Kamen et al ${ }^{7}$ indicate that same sex is faced with health-related problems especially mental health. Haber, for instance, espouses that more than a third of youth who are gay in the United States of America face victimization by family members, peers at school and the community. ${ }^{8}$ The fear and stress attributed to these discrimination results in these youth having low self-esteem, depression, drug abuse, etc.

A research conducted in Ghana also revealed that adolescents who identified as gay had a high prevalence of self - harm as compared to those who are heterosexual. ${ }^{9}$ Article 5 of the Universal Declaration of Human Rights states that "no one shall be subjected to torture or cruel, inhuman or degrading treatment or punishment". ${ }^{10}$ However, in countries where same sex marriages are not recognized or are deemed illegal, people who identify as gay are victimized and subjected to ill-treatment. In Islamic countries for instance, same-sex relationships of any kind are defined as sinful and to a larger extent punishable by death. ${ }^{11}$ All these actions have a negative impact on the health of same sex couples and affects their children in the long run.

\section{SUGGESTING WAYS OF CO-EXISTENCE}

In an era where the LGBT community are increasingly open, acknowledged and have become a visible part of most societies across the globe, there is the need to find a meeting point for parties with differing views on the issue of same sex marriage.

For Christians, the scriptural position on homosexuals and same-sex marriage must be maintained. Due to the power with which the bible has been enforced, it is only appropriate for all Christians to maintain and sustain the scriptural position of rejection. This is because the Holy Bible is the final authority of faith and practice. It sets up the criteria for qualification as a Christian. However, it is strongly admonished that anti-homosexuality sentiments and hostilities be managed. The following ways are suggested to ensure that Christians manage their

\footnotetext{
${ }^{1}$ Francesco Zaccaria, "Catholic Church, Young people and Human Rights," in Religion and Human Rights: An International Perspective, eds. Hans-Georg, Ziebertz and Ernst Hirsch Ballin (Switzerland: Springer, 2015): 99.

${ }^{2}$ Greenfeld and Seli, "Assisted Reproduction in Same Sex Couples," 74.

${ }^{3}$ Dorothy A. Greenfeld and Emre Seli, “Assisted Reproduction in Same Sex Couples" in Principles of Oocyte and Embryo Donation, ed. Mark V. Sauer (London: Springer, 2013): 289.

${ }^{4}$ Ronald Munson, Intervention and Reflection: Basic Issues in Bioethics (Boston: Wardsworth Cenage Learning, 2014$), 231$.

5 American Psychological Association, "Guidelines for Psychotherapy with Lesbian, Gay and Bisexual Clients" in. Psychological Perspectives on Lesbian, Gay, and Bisexual Experiences, eds. Linda Garnets and Douglas C. Kimmel (New York: Columbia University Press, 2003), 764.

${ }^{6}$ David Haber, Health Promotion and Aging: Practical Applications for Health Professionals. $6{ }^{\text {th }}$ ed. (New York: Springer Publishing Company, 2013).

${ }^{7}$ Charles Kamen et al, "Disparities in Psychological Distress Impacting Lesbian, Gay, Bisexual and Transgender Cancer Survivors," Psychooncology 24, no.11 (2015): 1384-1391, httl://doi:10.1002/pon.3746.

${ }^{8}$ Haber, Health Promotion and Aging, 366.

${ }^{9}$ Emmanuel N. B. Quarshie, Mitch G. Waterman and Allan O. House, "Prevalence of Self-Harm among Lesbian, Gay, Bisexual, and Transgender Adolescents: A comparison of personal and social adversity with a Heterosexual Sample in Ghana," BMC Research Notes 13, no.1(3 $3^{\text {rd }}$ June 2020): 271, http|://doi:10.1186/s13104-020-05111-4.

${ }^{10}$ United Nations, "Universal Declaration of Human Rights," accessed $11^{\text {th }}$ September, 2020, https:/www.un. org/en/universal-declarationhuman-rights/index.html.

${ }^{11}$ John Corvino and Maggie Gallagher, Debating Same-Sex Marriage (New York: Oxford University Press, 2012 ), 1.
} 
sentiments towards same-sex marriage in order to promote co-existence.

\section{- Attributional discourse: orienting the heterosexual Christian}

Many studies on same-sex unions in Africa have largely outlined the negative perceptions levelled against the act. According to Gyasi-Gyamerah et al, it is overwhelmingly documented that Africans' attitude towards homosexuals in Africa are largely negative, however there appears the lack of extensive exploration of interventional measure for change. In response, they propose the attributional discourse as a means to change Ghanaians' attitudes towards gays and lesbians. ${ }^{1}$ Among the major common questions in Ghana about Christianhomosexual relationship are 'can a homosexual be a Christian?' and 'what are God's plan or purpose for homosexuals?' In Ghana, there is evidence of gay/lesbian Christians and private homosexual white weddings are on the increase. However, the general Christian attitude towards same-sex couples remains undesirable. It has been a case of detest for both the act and the person involved in the act. Engaging the power of 'Attributional Discourse', the findings of Gyasi-Gyamerah et al reveal the need to ensure the existence of healthy attributional discourse over the rationality in homosexual decisions and behaviours. ${ }^{2}$ Their verdict is that public education on reasons behind homosexual acts is a possible means for reducing adverse attitudes of Ghanaians towards homosexuals.

\section{- Accommodating and supporting homosexuals: love of God, for God and for humans.}

Many Christian and human rights advocacy groups have challenged many Ghanaians to halt avoiding, discriminating and using derogatory words or phrases in describing persons involved in homosexual acts. In an interview with a young man who identified himself as being a homosexual on the Late Afternoon Show by Berla Mundi on GHOne TV, the young man whose name is Junior mentioned how he was physically abused by his dad for acting as a female. However, that did not stop him from embracing his sexuality. ${ }^{3}$ Similarly, Berla in another TV programme, The Day Show on TV3 interviewed three persons who identified as belonging to the LGBT community in Ghana. ${ }^{4}$ Among other things, the interviewees expressed their worry about the negative attitudes meted to them by the public. The disdain towards homosexuality was reaffirmed when some Ghanaian youth stormed the premises of TV3 during the live broadcast to halt the programme from being aired. The host was even criticised for promoting the agenda of the LGBT community. It can be asserted that a greater populace of the Ghanaian society identifies as Christians, hence there is an expectation from them to exhibit Christ-like attitude in such situations. Rather than discriminating, abusing and assaulting homosexuals or people in same sex marriages, they are to engage in meaningful acts of love towards homosexuals in order to formulate a meaningful relationship. The more Christians stop treating people in the LGBT community as 'evangelistic projects' or 'those people, ${ }^{5}$ the more meaningful relationships will develop. The love of God, for God and humanity will only exist if Christians engage in meaningful relationships with homosexuals. This relationship can be achieved through the following means:

- Meting out dignified treatments to homosexuals or partners in same sex marriages and understanding their reasons for their choices or decisions. Avoid prejudice at all cost.

- Developing friendships through church meetings and other religious services by way of conversations and seek not to correct anyone, but point to Christ.

- Also, teach them the word of God which contains His love for all created things and the avoidance of forbidden acts.

It is the responsibility of Christians to love all people and journey with them into God's kingdom. It must be agreed that a theological conviction is never a catalyst to maltreat any person.

\section{- Spiritual warfare against demonic orchestrations}

In the 'Demons' Reaction to Sodomy', Tamar Hezig reiterates that for four centuries now, theologians and demonologists have taught that "demons are actively engaged in 'homosexual relations during the witches' sabbath" which is believed to give them power over earthly ones. This idea can be seen as shaping the way that Christians have responded to the issue of homosexuality. There is quite a notion that homosexual relationship is demonic. The gay rights agenda is therefore seen as a satanic conspiracy to impose homosexuality on Africa. Oslon and Cadge exploring the views of mainline Protestants on the issue of homosexuality and how the church can handle it reveal divisive opinions held by the church-clergy. ${ }^{7}$ A greater number of church ministers openly

\footnotetext{
${ }^{1}$ Angela A. Gyasi-Gyamerah, Christopher M. Amissah and Samuel A. Danquah, "Changing Attitudes toward Homosexuality in Ghana: The Power of Attributional Discourse," Sage Open 9, no.2 (2019): 1.

${ }^{2}$ Gyasi-Gyamerah, Amissah and Danquah, "Changing Attitudes toward Homosexuality in Ghana," 6.

${ }^{3}$ Junior, "Homosexuality in Ghana," interview by Berla Addardey (alias Bella Mundi), GHOne TV, Late Afternoon Show, December, 13 2017, audio, 14:35, https://youtu.be/bUHVbfiOtDc.

4 "Gender Dysphoria," interview by Berla Addardey (alias Bella Mundi), TV3 Ghana, The Day Show, May 2, 2020, audio, 40:22, https://www.youtube.com/watch?v=XiZM_H7S90\&t=449s/.

${ }^{5}$ Some Men of God use expressions like 'those people' in some evangelistic projects in Ghana.

${ }^{6}$ Tamar Hezig, "Demons' Reaction to Sodomy: Witchcraft and Homosexuality in Gianfrancesco Pico della Mirandola's Strix," Sixteenth Century Journal XXXIV, no.1 (2003): 54-72.

${ }^{7}$ Laura R. Olson and Wendy Cadge, "Talking about Homosexuality: The Views of Mainline Protestant Clergy," Journal for the Scientific Study of
} 
shared their disapproval to gay and lesbian rights and illustrated the danger the issue poses for the church. On the other hand, a few of them could not fathom why gay and lesbian people are detested by organized religion. The views expressed by most of these clergy affirms the church's notion that homosexuality is not a natural phenomenon but rather from the devil. Hence, acts that are seen as demonic cannot be accepted into the church. ${ }^{1}$ In 2006, for instance, Rev. Ted Haggard, an American evangelical pastor was fired from his post after a former male prostitute, Mike Jones, accused him of paying for sex on a monthly basis for three years. To his followers, Haggard was harassed by real demons of sexual deviance, dark and revolting forces he had been battling his entire life; Haggard conceded their presence and influence by calling himself "a liar and a deceiver," names commonly attributed to Satan thus, Haggard was ill, and he needed to be restored to spiritual health. In other words, he needed to be "delivered."

Several means of punishment are adopted by the church in dealing with this 'demonic' issue and some include excommunicating homosexual members, healing them through prayer, therapy and exorcism. According to evangelist Dag Heward-Mills ${ }^{3}$, the only way to eradicate this demonic possession in the form of homosexuality is to be spiritual; praying, reading the Bible and focusing on God. This will lead them to being saved. ${ }^{4}$ Therefore, in addressing the issue of same-sex marriage, one ought not to play with his/her spiritual life; pray on a daily basis to resist the devil and his cohorts, read the Bible, be spiritually strong so as to be able to desist from such act.

\section{CONCLUSION}

Ghana has a mixed record on its treatment of lesbian, gay, bisexual and transgender (LGBT) people. It criminalizes "unnatural carnal knowledge" in section 104 (1) (b) of its Criminal Offences Act. Ghana has not taken steps in recent years to stiffen penalties against consensual same-sex conduct or to expressly criminalize sexual relations between women. Government agencies such as, the Ghana Police Force and the Commission on Human Rights and Administrative Justice (CHRAJ), have reached out to LGBT people and taken proactive steps, including through providing human rights training workshops to help ensure their protection.

The issue of same-sex marriage is far from being settled in the Ghanaian Christian circle. Christians respond to same-sex relationship with reference to what scripture teaches. In the Christian scripture is a strong rejection of same-sex intercourse. This emanates from the belief that the genetic make-up of both the male and female sexes is of divine origin. Both sexes were created to complement each other. It is through this complimentary nature that marital bonds, communion and stability is displayed. However, in spite of the outright detest for the same-sex acts, this paper suggests a meeting point of co-existence. Though, scripture, bioethics and health law appear to share differing views on same-sex marriage, orienting the heterosexual Christian, accommodating and supporting homosexuals have been described in this work as better ways for coexistence in Ghana.

\section{References}

Akande, B. S. Traditional Marriage Institution Among Ogori/Magongo People of Kogi State. Lagos: Obaino Limited, 1997.

Amenga-Etego, Rosemary. "Marriage without Sex? Same-Sex Marriages and Female Identity among the Nakani of Northern Ghana." Ghana Bulletin of Theology 12 (December 2012): 14-37.

American Psychological Association. "Guidelines for Psychotherapy with lesbian, gay, and Bisexual Clients." In Psychological Perspectives on Lesbian, Gay and Bisexual Experiences, edited by Linda Garnets and Douglas Kimmel, 740-56. New York: Columbia University Press, 2003.

Corvino, John and Gallagher, Maggie. Debating Same-Sex Marriage. New York: Oxford University Press, 2012.

DeRogatis, Amy. "Born Again is a Sexual Term: Demons, STD's and God's Healing Sperm." Journal of the American Academy of Religion 17, no.2 (2009): 275-298.

Dershowitz, Idan. "Revealing Nakedness and Concealing Homosexual Intercourse: Legal and Lexical Evolution in Leviticus 18." Journal Hebrew Bible and Ancient Israel 6, no.4 (2017): 510-526.

Edmonds, Janet. "An Analysis of the Seven Scriptures Often Referred to as 'The Clobber Verses"," accessed February 17, 2021, https://serendipitydodah.wordpress.com /2017/02/27/the-clobber-verses/.

Elwell, Walter A. Evangelical Dictionary of Theology. Michigan: Baker Academic, 2001.

Enze, Han and O'Mahoney, Joseph. British Colonialism and the Criminalization of Homosexuality: Queens, Crime and Empire. London: Taylor \& Francis Limited, 2019.

\footnotetext{
Religion 41, no. 1 (2002): 153-67.

${ }^{1}$ Laura and Cage, "Talking About Homosexuality," 157.

${ }^{2}$ DeRogatis Amy, "Born Again is a Sexual Term: Demons, STD’s and God's Healing Sperm," Journal of the American Academy of Religion, 7, no.2 (2009): 275.

${ }^{3}$ Evangelist Dag Heward-Mills is an African Evangelist, the founder and general overseer of the United Denominations Originating from the Lighthouse Group of Churches (UD-OLGC), formerly Lighthouse Chapel International.

${ }^{4}$ Dag Heward-Mills, Demonology: A Concise Study (London: Parchment House, 2005), Chap.24.
} 
Goddard, Andrew. "Theology and Practice in Evangelical Churches." In The Oxford Handbook of Theology, Sexuality, and Gender, edited by Adrian Thatcher, 380-390. Oxford: University Press, 2015.

Greenfeld, Dorothy A. and Emre Seli. "Assisted Reproduction in Same Sex Couples." In Bioethics: An Anthology ( $3^{\text {rd }}$ Ed.), edited by Helga Kuhse, Udo Schuklenk and Peter Singer, 74-84. West Sussex: Willey Blackwell Publisher, 2016.

Greenfeld, Dorothy A. and Emre Seli. "Assisted Reproduction in Same Sex Couples." In Principles of Oocyte and Embryo Donation, edited by M.V. Sauer, 289-301. London: Springer, 2013.

Gyasi-Gyamerah, Angela A. Christopher M. Amissah and Samuel A. Danquah. "Changing Attitudes toward Homosexuality in Ghana: The Power of Attributional Discourse." Sage Open 9, no.2 (2019): 1-9.

Haber, David. "Health Promotion and Aging: Practical Applications for Health Professionals" 6th ed. New York: Springer Publishing Company, 2013.

Hamilton, Frances and Guido Noto La Diega (eds). Same-Sex Relationships, Law and Social Change. London: Taylor \& Francis, 2020.

Heward-Mills, Dag. Demonology: A Concise Study. London: Parchment House, 2005.

Hezig, Tamar. "Demons' Reaction to Sodomy: witchcraft and homosexuality in Gianfrancesco pico della Mirandola's strix." Sixteenth Century Journal XXXIV, no.1 (2003): 54-72.

Holton, Kevin T. The Abolition of Marriage: Freeing the Right to Be Religious and Leaving the Left Alone. London: Hamilton books, 2020.

Junior, "Homosexuality in Ghana." Interview by Berla Addardey. GHOne TV, Late Afternoon Show, December 13, 2017. Audio, 14:35. https://youtu.be/bUHVbfiOtDc.

Kamen C., Mustian, K. M., Dozier, A., Bowen, D. J. and Li, Y. "Disparities in psychological distress impacting lesbian, gay, bisexual and transgender cancer survivors." Psychooncology 24, no.11 (January 2015): 13841391. doi:10.1002/pon .3746.

Kunhiyop, W. Samuel. African Christian Ethics. Nairobi: Hippo books, 2008.

Munson, Ronald. Intervention and Reflection: Basic Issues in Bioethics, Concise Edition. Boston: Wards Worth Cengage Learning, 2014, 189-237.

Olson, R. Laura and Cadge, Wendy. "Talking about Homosexuality: The Views of Mainline Protestant Clergy." Journal for the Scientific Study of Religion 41, no. 1 (2002): 153-67. http://www.jstor.org/stable/1387718.

Peschke, H. Karl. Christian Ethics: Moral Theology in the Light of Vatican II. Bangalore: Theological Publications, 2010.

Quarshie, N. B. E., Waterman, Mitch G. and House, Allan O. "Prevalence of Self-Harm Among Lesbian, Gay, Bisexual and Transgender Adolescents: A Comparison of Personal and Social Adversity with a Heterosexual Sample in Ghana." BMC Research Notes 13, no.1 (June 2020): 271-273. doi: 10.1186/s13104-020-05111-4.

Rettner, Rachael. "How Same-Sex Marriage Ruling Could Improve Health," accessed 17th February, 2021. https://www.livescience.com/51368-same-sex-marriage-health.html.

Salm, J. Steven and Falola, Toyin. Culture and Customs of Ghana. London: Greenwood Publishing Group, 2002.

Schafer, Steven. Marriage, Sex, and Procreation: Contemporary Revisions to Augustine's Theology of Marriage Vol. 240. London: Wipf and Stock Publishers, 2019.

Silberling, Murray. The Seven Year Contract: Fixing the Institution of Marriage. Booklocker.com, Incorporated, 2013.

Smith, Wilfred Cantwel. What is Scripture? A Comparative Approach. Minneapolis: Fortress Press, 1994.

Solace Brothers Foundation et al. "Human Rights Violations Against Lesbian, Gay, Bisexual and Transgender (LGBT) People in Ghana: A Shadow Report” 8, (2016), https://tbinternet.ohchr.org/Treaties/CCPR/Shared\%20Documents/GHA/INT_CCPR_CSS_GHA_24149_E. pdf

United Nations. "Universal Declaration of Human Rights," accessed September 11, 2020, https://www.un.org/en/universal-declaration-human-rights/index.html.

Whitehead, Evelyn E. and Whitehead, James D. "The Meaning of Marriage." In Contemplating Marriage: Reader, edited by Gloria Blanchfield Thomas, 38-43. Wisconsin: Rowman \& Littlefield, 1995.

Winter, B., Forest, M. and Sénac, R. "Introduction." In Global Perspectives on Same-Sex Marriage: A NeoInstitutional Approach, edited by Bronwyn Winter, Maxime Forest and Réjane Sénac, 1-18. London: Springer, 2017.

Zaccaria, Francesco. "Catholic Church, Young people and Human Rights" In Religion and Human Rights: An International perspective, edited by Hans-Georg, Ziebertz and Ernst Hirsch Ballin, 93-102. Zurich: Springer, 2015. 